\title{
Foreign Aid, Donor Fragmentation, and Economic Growth
}

\author{
Kurt Annen \\ Department of Economics and Finance, University of Guelph \\ kannen@uoguelph.ca \\ Stephen Kosempel \\ Department of Economics and Finance, University of Guelph \\ kosempel@uoguelph.ca

\section{Department of Economics and Finance University of Guelph Discussion Paper 2009-14}




\title{
The B.E. Journal of Macroeconomics
}

\author{
Contributions
}

Volume 9, Issue 1

2009

Article 33

\section{Foreign Aid, Donor Fragmentation, and Economic Growth}

\author{
Kurt Annen*
}

Stephen Kosempel ${ }^{\dagger}$

*University of Guelph, kannen@uoguelph.ca

†University of Guelph, kosempel@uoguelph.ca

\section{Recommended Citation}

Kurt Annen and Stephen Kosempel (2009) "Foreign Aid, Donor Fragmentation, and Economic Growth," The B.E. Journal of Macroeconomics: Vol. 9: Iss. 1 (Contributions), Article 33.

Available at: http://www.bepress.com/bejm/vol9/iss1/art33

Copyright (c)2009 The Berkeley Electronic Press. All rights reserved. 


\title{
Foreign Aid, Donor Fragmentation, and Economic Growth*
}

\author{
Kurt Annen and Stephen Kosempel
}

\begin{abstract}
This paper analyzes the impact of foreign aid on growth. It differs from the existing literature in at least two important ways. First, we differentiate between foreign aid as technical assistance and non-technical assistance, and demonstrate both theoretically and empirically that this distinction is important. Second, we test the hypothesis that the effectiveness of aid depends on its level of fragmentation. To preview our main results: non-technical assistance has no statistically significant impact on growth; but technical assistance has a positive and significant impact, except in countries where it is highly fragmented.
\end{abstract}

KEYWORDS: foreign aid, technical assistance, donor fragmentation, growth

${ }^{*}$ We are grateful for helpful remarks and suggestions to Ryan Compton, Brian Ferguson, Joniada Milla, Miana Plesca, Thanasis Stengos, Esteban Rossi-Hansberg, and two anonymous referees as well as to seminar and conference participants at the University of Manitoba and Guelph, Canadian Economic Association Meetings 2008 in Vancouver, and Small Open Economy in a Globalized World conference 2008 in Waterloo. The usual disclaimer applies. 
Annen and Kosempel: Foreign Aid, Donor Fragmentation, and Economic Growth

\section{Introduction}

Does foreign aid help countries grow? Are some forms of aid more effective than others? For many years economists and policymakers concerned with economic development have debated the answers to these important questions, but with little resolution. The debate over the effectiveness of aid remains unresolved for at least two reasons: First, in the background of this debate is a large empirical literature on the impact of foreign aid on growth, in which the evidence in support of a positive relationship between aid and growth is mixed. In this literature it is quite common for one paper to present a positive result, which is later overturned or qualified in a subsequent paper. Second, there exists a "micro-macro paradox" - projects funded by foreign aid often report positive micro-level returns, but these have been difficult to detect at the macro-level. In fact, the results obtained from some of the more recent papers in the empirical literature support the view that there is virtually no aggregate relationship between aid and growth across countries:

"... at best there appears to be a small, positive, but insignificant, impact of aid on growth." (Bourguignon and Sundberg, 2007)

“... we find little robust evidence of a positive (or negative) relationship between aid inflows into a country and its economic growth. We find virtually no evidence that aid works better in better policy or institutional or geographical environments, or that certain kinds of aid work better than others." (Rajan and Subramanian, 2008)

This paper argues that it is premature to draw strong policy conclusions on the basis of the current empirical literature for at least two reasons. First, we differentiate between foreign aid as technical assistance (TA) and non-technical assistance (NTA), and demonstrate both theoretically and empirically that this distinction is important. Second, we believe that there are scale economies associated with the provision of TA, and therefore its effectiveness may depend on how fragmented it is. In our empirical work we show that there is a strong interaction effect between donor fragmentation and TA, suggesting that the effectiveness of TA falls as fragmentation increases.

Within the context of a standard neo-classical growth model, we demonstrate that the effectiveness of aid depends on its type. TA is modeled as a knowledge transfer that is intended to improve productive capabilities in the recipient country, whereas NTA is treated as an income transfer that adds to available resources for consumption and investment. ${ }^{1}$ The theory says that TA, which affects productivity,

\footnotetext{
${ }^{1}$ Both types represent a substantial share of total aid. For example, in 2005 TA accounted for $52 \%$ of total current and actual transfers for the average recipient.
} 
should affect growth; whereas NTA, which enters the resource constraint, should not. In our empirical work we provide evidence in support of these predictions. In comparison, most of the current literature uses aid measures as an aggregate of many different forms of aid including emergency and food aid, and debt forgiveness of loans that were not originally intended for development projects (i.e. debtforgiveness of non-Official Development Assistance (ODA) loans). ${ }^{2}$ These aid measures are not specific enough. It is not surprising that such macro measures yield inconclusive results. In addition, in all of the current literature it is assumed that one dollar of aid equals one dollar of additional financial resources. However, the disbursement of foreign aid is costly. If the technology used for aid disbursements exhibits increasing returns to scale, then the effectiveness of a given amount of aid depends on how fragmented this amount of aid is. This is particularly true for TA. Donor countries that provide TA run local offices in recipient countries, or hire NGOs to run them on their behalf. To run these offices involves fixed costs in the form of maintaining offices typically in the fancier part of the capitals of developing countries, living expenses for foreign engineers and consultants, etc. This may suggest that the effectiveness of TA increases with the scale of the operation. There may be an interaction effect between TA and donor fragmentation. In fact, it will be demonstrated that foreign aid, when given in the form of technical assistance, has a positive and statistically significant impact on growth, except in countries where it is highly fragmented. ${ }^{3}$

The basic underlying framework for our theoretical analysis of the aid-growth relationship is the neo-classical growth model of Ramsey (1928)-Cass (1965)- Koopmans (1965). Following Mankiw, Romer, and Weil (1992), we extend the production side of the basic model to allow for the accumulation of both physical and human capital. Since NTA involves a transfer of income, it enters the model through the resource constraint. In comparison, TA enters the model through the human capital production function, and in this way the model's treatment of TA corresponds closely with the OECD's definition of it. TA is recorded by the OECD under technical cooperation, and is defined as follows: "Technical co-operation is defined as activities whose primary purpose is to augment the level of knowledge, skills, tech-

\footnotetext{
${ }^{2}$ Two exceptions are Clemens, Radelet, and Bhavnani (2004) and Minoiu and Reddy (2009). They observe that disaggregating aid measures is key for a better understanding of the impact of aid on growth.

${ }^{3}$ When calculating the fragmentation index, we follow Knack and Rahman (2007). Donor fragmentation has increased substantially between 1970 and 2005, namely from $40 \%$ to $62 \%$. In 2005 , countries like Vietnam (86\%), Nicaragua (86\%), Gambia (85\%), and Bangladesh (82\%) had the highest levels of donor fragmentation; whereas countries like Comoros $(7.3 \%)$ and Solomon Islands $(7.7 \%)$ had the lowest levels of fragmentation, with France and Australia as the major donors respectively.
} 
nical know-how or productive aptitudes of the population of developing countries, i.e., increasing their stock of human intellectual capital, or their capacity for more effective use of their existing factor endowment." Technical assistance is intended to fill skills and knowledge gaps in developing countries. TA comes in two forms: It is either linked to other aid projects, providing the technical component and knowhow for these aid projects, or TA constitutes free-standing initiatives focusing on training and skills transfer (Riddell, 2007, p. 203). The distinction between TA and NTA matters. In the model, an increase in TA promotes income growth because it affects productivity no matter whether the change in TA is perceived as being permanent or temporary. In contrast, the model predicts that NTA is consumed entirely if the change is perceived as being permanent. In this case, NTA does not promote income growth.

The papers that most closely resemble the theoretical component of this paper are Chatterjee, G., and Turnovsky (2003), Dalgaard, Hansen, and Tarp (2004), Hodler (2007), Chatterjee, Giuliano, and Ilker (2007), Chatterjee and Turnovsky (2007) and Agenor, Bayraktar, and Aynaoui (2008). The main feature that distinguishes these earlier papers from ours is that they only consider income transfers, whereas we also consider the transfer of knowledge. In several of the papers mentioned above, aid funds were allowed to be used to finance public infrastructure, and therefore - like TA - these funds may also have a productivity enhancing effect. However, unlike other forms of aid, one advantage of TA is that it is not fungible. ${ }^{4}$ The aid literature claims that fungibility may render most aid distinctions meaningless. ${ }^{5}$ However, TA is to our knowledge mainly disbursed by the donor countries themselves or by NGOs working for donor countries. Thus, the view that aid is in the form of a check that the government of a recipient country can spend at its own discretion does not apply to TA. ${ }^{6}$

In our empirical work we estimate the impact of technical- and non-technical assistance on economic growth using the GMM system estimator developed by Arellano and Bond (1991) and Blundell and Bond (1998). One of the advantages of this estimator is that we do not need to deal with country specific effects such as institutional and cultural variables that are difficult to measure. ${ }^{7}$ We include policy measures that control for a changing policy environment across time. This paper finds, first, a strong interaction effect between TA pc and donor fragmentation. The

\footnotetext{
${ }^{4}$ Aid funds that are intended to help finance specific activities often merely substitute for spending that recipient governments would have undertaken anyway.

${ }^{5}$ see Devarajan and Swaroop (1998).

${ }^{6} \mathrm{TA}$ is a form of tied aid as opposed to un-tied aid. See Amegashie, Quattara, and Strobl (2007) for an economic model explaining why donor countries may use tied- as opposed to un-tied aid.

${ }^{7}$ See Glaeser, La Porta, Lopez-de Silanes, and Shleifer (2004) for a critical discussion of the institutional variables typically used in the literature.
} 
partial impact of TA pc decreases as donor fragmentation increases. We obtain this finding no matter the time frame considered. Our result is also robust to the exact specification of the empirical model and the normalization of aid used. For our main result we use the System GMM estimator, but we obtain a similar result for the time horizon between 1970 and 2004 using IV estimation with an instrumentation strategy similar to the one used in Rajan and Subramanian (2008). Second, the estimates suggest that tripling TA pc for the country receiving an average amount of TA pc would increase its income growth rate by about 3 percentage points if donor fragmentation is zero. ${ }^{8}$ However, for the country with an average fragmentation level, we find no significant positive impact of TA pc on income growth at the five percent level. ${ }^{9}$ Our result for donor fragmentation suggests that donor fragmentation produces inefficiencies that greatly reduce the effectiveness of TA. From a policy perspective, this paper provides evidence that the coordination of aid among donors is critical.

The papers most closely related to the empirical component of this paper are Minoiu and Reddy (2009) and Clemens, Radelet, and Bhavnani (2004). Both papers disaggregate the ODA measure into different forms of aid. Minoiu and Reddy (2009) focus on aid which is developmental and non-developmental. They refer to aid that was given for geopolitical reason as non-developmental while the remaining aid is called developmental. They use an aid allocation regression to obtain their measures. Using similar estimation techniques than here, they show that developmental aid has a significant positive impact on growth in the long run. Clemens, Radelet, and Bhavnani (2004) divide aid into three categories: humanitarian, longrun impact, and short-run impact aid. They find a strong positive causal relationship between short-impact aid and growth. These two papers suggest that disaggregating aid measures is a promising way of getting a better understanding of aid on growth. Our paper follows these approaches by distinguishing between aid in form of technical assistance and non-technical assistance. However, unlike these earlier papers, we also study the impact of donor fragmentation on aid effectiveness. Our work on donor fragmentation is related to a recent paper by Knack and Rahman (2007). They show that donor fragmentation is inversely related to bureaucratic quality of recipient countries. However, they do not link donor fragmentation to aid effectiveness.

The rest of the paper is organized as follows. Section 2 outlines the theoretical model. Section 3 presents the empirical results. Section 4 evaluates the robustness of the results. Finally, Section 5 concludes.

\footnotetext{
${ }^{8}$ To give 0.7 percent of their GNP as official development assistance is often discussed as a target in policy circles, which means that aid would more than triplicate from 0.2 percent of GNP in 2002.

${ }^{9}$ But note that in a specification without donor fragmentation, the coefficient for TA pc is positive and significant at the ten percent level.
} 


\section{Aid and Growth: Theoretical Analysis}

This section provides the theoretical rationale for disaggregating aid according to whether it takes the form of TA or NTA. ${ }^{10}$ The basic framework is due to Ramsey (1928), Cass (1965) and Koopmans (1965). However, following Mankiw, Romer, and Weil (1992), we extend the production side of the basic model to allow for the accumulation of both physical and human capital. The convention throughout the paper is to use upper case letters to denote per capita variables, lower case letters to denote variables that have been transformed into effective labor units, a star superscript $(*)$ to denote a long-run or steady-state value, and a dot over a variable to denote a time derivative.

We consider a closed economy populated by a large number of infinitely lived and identical households. The size of each household grows at rate $n$. The representative household seeks to maximize lifetime utility by choosing an optimal path for consumption and investment. The lifetime utility function is given by

$$
U=\int_{t=0}^{\infty} u[C(t)] e^{-(\rho-n) t} d t
$$

where $C(t)$ denotes consumption per person, and $\rho$ is the constant rate of time preference. The instantaneous utility function is assumed to take the constant intertemporal elasticity of substitution form

$$
u[C(t)]=\frac{C(t)^{1-\theta}-1}{1-\theta},
$$

where $\theta>0$ is the reciprocal of the elasticity of intertemporal substitution.

In a given recipient country of foreign aid, each household-producer has access to a Cobb-Douglas constant returns to scale production technology

$$
\begin{aligned}
& Y(t)=X(t)^{1-\alpha-\beta} K(t)^{\alpha} H(t)^{\beta}, \\
& X(t)=X(0) e^{g t} .
\end{aligned}
$$

Here, $Y(t)$ denotes GDP per person, $K(t)$ and $H(t)$ are the levels of physical and human capital per person, $X(t)$ is the level of labor augmenting technology, and $g$ is the constant rate of technological change. Following most of the empirical growth literature, it is assumed that the value of $g$ is the same for all countries. However, countries may differ with respect to their initial productivity level, $X(0)$.

\footnotetext{
${ }^{10}$ Easterly (2003) observes the lack of theoretical models on the aid growth relationship which help to pin down the specification needed for empirical analysis.
} 
The country receives aid in the form of technical and non-technical assistance. Non-technical aid affects the resource constraint, which is given by

$$
Y(t)+N T A(t)=C(t)+I_{K}(t)+I_{H}(t),
$$

where $N T A(t)$ denotes non-technical assistance per capita; and $I_{K}(t)$ and $I_{H}(t)$ denote investment in physical and human capital respectively. In contrast, technical assistance is assumed to affect the productivity of human capital production, because it is a transfer of knowledge. The laws of motion for capital are then given by

$$
\begin{aligned}
\dot{K}(t) & =I_{K}(t)-(\delta+n) K(t), \\
\dot{H}(t) & =\sigma[T A(t) / X(t)] \times I_{H}(t)-(\delta+n) H(t),
\end{aligned}
$$

where $\delta$ denotes the rate of capital depreciation, $\sigma$ is a function that describes productivity in human capital production, and $T A(t)$ is technical assistance per capita. A specific functional form for $\sigma$ will not be required. We, however, assume: $\partial \sigma / \partial T A>0, \partial^{2} \sigma /(\partial T A \cdot \partial X)<0$, and $\sigma(0)=1$. These assumptions imply that $T A$ has a positive effect on the productivity of human capital production, and therefore it enters into the model in a way that corresponds closely to the OECD definition of technical co-operation, that is, as activities whose primary purpose is to augment the level of knowledge, skills, technical know-how, or productive aptitudes of the population of the recipient countries. Furthermore, our assumptions imply that TA is not an essential input into human capital production, and that TA will be more effective in countries with relatively low levels of the labor augmenting technology. In other words, TA will be more effective when given to countries that are farther from the world technology frontier. ${ }^{11}$

Finally, to complete the model, aid payments are assumed to grow in proportion to the income in donor countries. As indicated above, all countries are assumed to have a common long-run growth rate, and therefore:

$$
\begin{aligned}
N T A(t) & =N T A(0) e^{g t} . \\
T A(t) & =T A(0) e^{g t} .
\end{aligned}
$$

The optimality conditions with respect to the representative household's choices of $C, I_{K}$ and $I_{H}$ are

$$
\begin{aligned}
C(t)^{-\theta} e^{-(\rho-n) t} & =\psi(t), \\
-\psi(t)[\alpha Y(t) / K(t)-\delta-n] & =\dot{\psi}(t), \\
-\psi(t)[\beta \sigma(t) Y(t) / H(t)-\delta-n] & =\dot{\psi}(t),
\end{aligned}
$$

\footnotetext{
${ }^{11}$ In Mankiw, Romer, and Weil (1992) the production functions for physical and human capital are identical; whereas here they will differ if a country is a recipient of TA, because TA lowers the cost of acquiring an additional unit of human capital.
} 
where $\psi(t)$ is the present-value shadow price of income. These conditions imply that the optimal solution to the representative household's maximization problem requires that households set their investment levels to equalize rates of return between the two types of capital. This produces the following ratio of human-tophysical capital:

$$
H(t)=\left[\frac{\beta \sigma(t)}{\alpha}\right] K(t) .
$$

In turn, this result is used to substitute out for $H$, and reduce the model to a system of two differential equations and two unknowns $(C$ and $K)$. The maximization of the representative household's lifetime utility implies that the growth rate of consumption per effective unit of labor $(c \equiv C / X)$ and capital per effective unit of labor $(k \equiv K / X)$ at each point in time are given by

$$
\begin{aligned}
\frac{\dot{c}(t)}{c(t)} & =\frac{1}{\theta}\left(\alpha A k(t)^{\alpha+\beta-1}-\delta-\rho-\theta g\right), \\
(1+\beta / \alpha) \dot{k}(t) & =A k(t)^{\alpha+\beta}+n t a-(\delta+n+g)(1+\beta / \alpha) k(t)-c(t),
\end{aligned}
$$

where

$$
A \equiv\left[\frac{\beta}{\alpha} \sigma(t a)\right]^{\beta} .
$$

Here $n t a$ and $t a$ are constants and denote the levels of non-technical and technical aid per effective unit of labor.

A well known feature of the basic Ramsey-Cass-Koopmans model is that it exhibits saddle path stability. Although the basic structure has been augmented to incorporate foreign aid, the equilibrium is still a saddle point. ${ }^{12}$ The phase diagram for the model is displayed in Figure 1. Expressions for the $\dot{c}=0$ and $\dot{k}=0$ loci are given by:

$$
\begin{aligned}
& \dot{c}=0 \Rightarrow k^{*}=\left[\frac{\alpha A}{\delta+\rho+\theta g}\right]^{\frac{1}{1-\alpha-\beta}}, \\
& \dot{k}=0 \Rightarrow c^{*}=A\left(k^{*}\right)^{\alpha+\beta}+n t a-(\delta+n+g)(1+\beta / \alpha) k^{*} .
\end{aligned}
$$

\footnotetext{
${ }^{12}$ The saddle path property can be verified by log-linerizing the dynamic system for $c$ and $k$ around the steady state and showing that the determinant of the characteristic matrix is negative. A closed form solution exists for the log-linearized version. The solution for the growth rate of per capita output over an interval from some initial time 0 to a future time $T \geq 0$ is given by

$$
\frac{\ln Y(T)-\ln Y(0)}{T}=g+\frac{\left(1-e^{-\lambda T}\right)}{T}\left[\ln X(0)+\ln y^{*}-\ln Y(0)\right]
$$

where $\lambda$ is the speed of convergence. This is the base equation for the empirical part of this paper.
} 
Since the general properties of the model are well known, our discussion focuses only on how an economy will respond to a change in its levels of foreign aid. Since the two different forms of aid enter differently into the model, the comparative statics properties are distinct.

First, consider the effects of an increase in the level of technical assistance. Suppose that the economy is in the long-run equilibrium (at point $E$ in panel (a) in Figure 1), and there is an unexpected, permanent increase in technical assistance: $t a \rightarrow t a^{\prime}$. The increase in $t a$ lowers the cost of acquiring an additional unit of human capital, and therefore the stock of human capital rises. In turn, this increases the marginal product of physical capital, which shifts the $\dot{k}=0$ locus up and the $\dot{c}=0$ locus to the right. ${ }^{13}$ The economy jumps to a new saddle path $\left(S P \rightarrow S P^{\prime}\right)$, and proceeds to a new long-run equilibrium at $E^{\prime}$, which has more capital and higher output. ${ }^{14}$ In comparison, if the change was perceived as being temporary, then the long-run equilibrium would remain at $E$. However, the influx of $t a$ would still temporarily lower the cost of acquiring human capital. As such, an economy that was initially at E, would over accumulate capital relative to the long-run level, and income growth would be temporarily high. However, if the terminal date was known, then when the aid level returned to normal, the economy would find itself back on the saddle path SP to the initial equilibrium. ${ }^{15}$

Next, consider the effects of an increase in the level of non-technical assistance. Once again suppose that there is an unexpected permanent increase in non-technical assistance when the economy is in the long-run equilibrium (at point $E$ in panel (b) in Figure 1): nta $\rightarrow n t a^{\prime}$. The increase in $n t a$ raises the amount of resources available for consumption and investment, and therefore shifts the $\dot{k}=0$ locus (parallel) upwards. However, unlike technical assistance, nta does not have a direct effect on productivity or the rate of return to capital, and therefore the $\dot{c}=0$ locus is unaffected. The economy jumps to a new saddle path, with a higher level of consumption. Notice that the economy moves instantaneously to its new long-run equilibrium, and this is because the long-run level of capital has not changed. The savings rate applied to additional $n t a$ is zero. Instead of saving out of new aid money, households obtain their desired consumption profile by consuming it all

\footnotetext{
${ }^{13}$ This can be seen in the expressions above since the productivity parameter, $A$, depends positively on $t a$.

${ }^{14}$ The initial effect on consumption is ambiguous, but it rises in the long-run.

${ }^{15} \mathrm{~A}$ similar analysis applies to an economy in transition. In the case of a unexpected, permanent increase in $t a$, the additional aid pushes the economy farther from the steady-state position, and therefore leads to faster growth in income. For the temporary case, the economy will operate off the saddle path during the periods in which the additional aid is received. Investment will rise during periods in which additional $t a$ is available, and this is because the economy will take advantage of the relatively low cost of acquiring human capital.
} 
Annen and Kosempel: Foreign Aid, Donor Fragmentation, and Economic Growth

(a) An increase in technical assistance

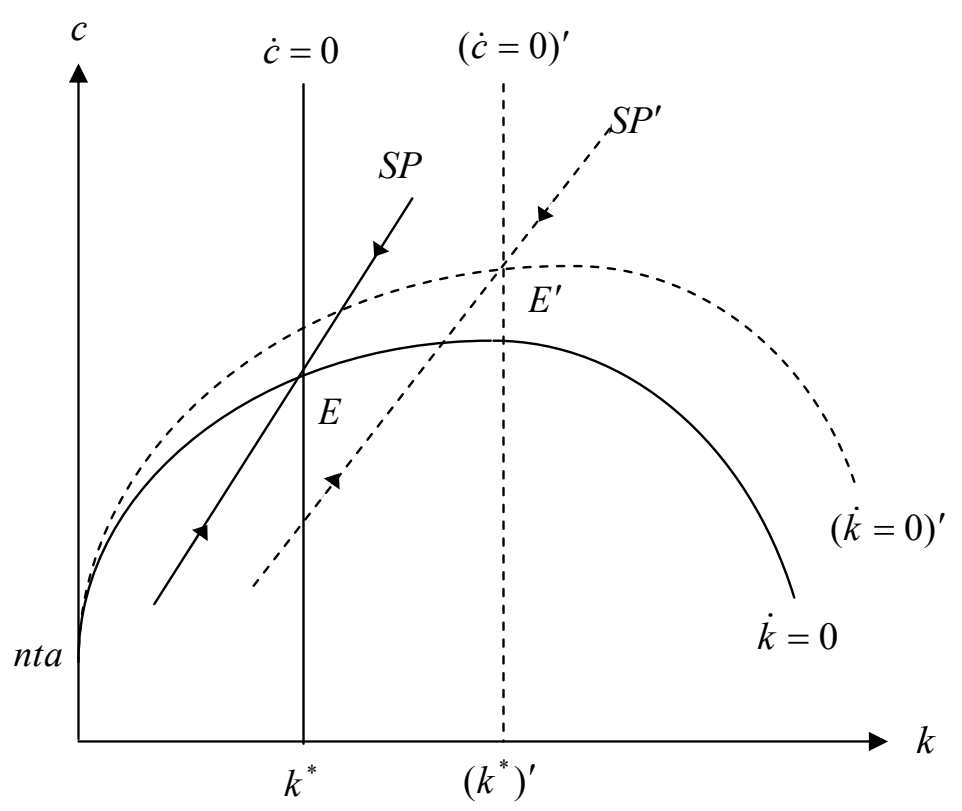

(b) An increase in non-technical assistance

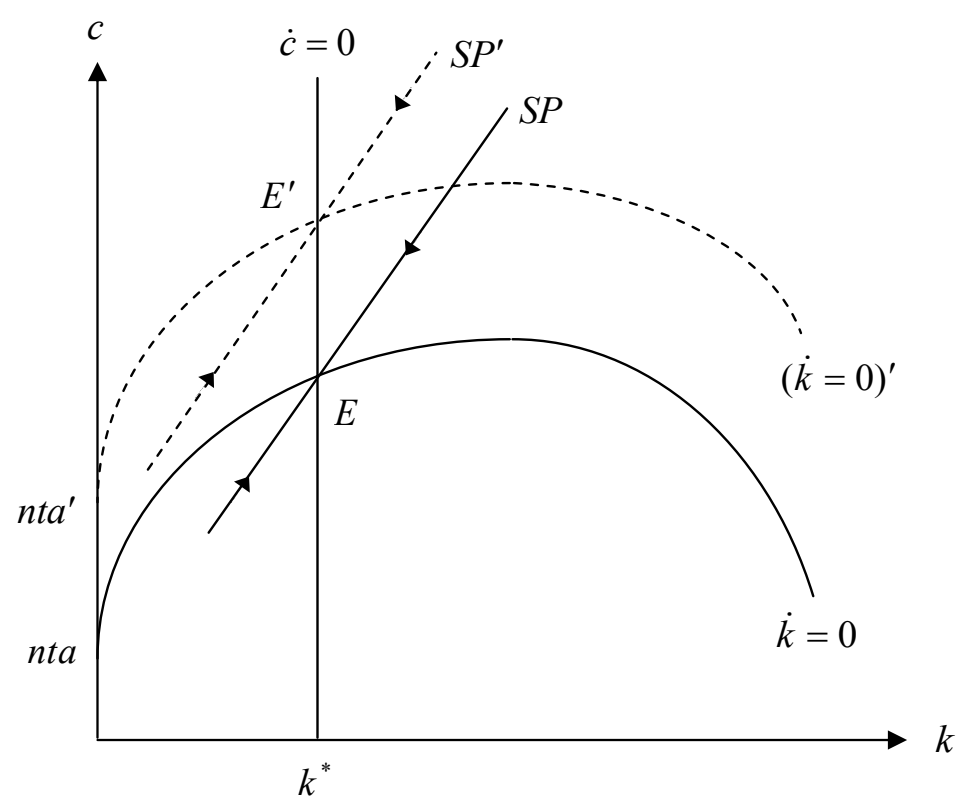

Figure 1: Phase Diagram

Published by The Berkeley Electronic Press, 2009 
each period. In comparison, if the change was perceived as being temporary, then the long-run equilibrium would remain at $E$. However, the economy will initially follow a path away from $E$, and therefore it will over accumulate capital relative to the steady-state level. If the terminal date is known with certainty, then the economy must find itself back on the saddle path exactly when the aid level returns to normal. The intuition for this result is that in order to smooth their consumption profile, households will optimally save (or invest) some of the additional nta. The additional savings will be used to support relatively high consumption levels when aid payments revert back to normal levels, and therefore consumption levels will follow a smooth transition. The more temporary the change is perceived, the larger will be the effect on the savings rate, the capital stock, and output.

Note that for both types of aid the responses follow standard macro-intuition. For TA, responses are identical to models with investment specific technical change. In those models, an investment specific technology shock affects the relative price of physical capital, whereas in our model a change in TA affects the relative price of human capital. For NTA, responses follow directly from the permanent income hypothesis.

In summary, the model reveals that foreign aid can have a positive effect on growth of income per capita in poor countries. This prediction of the model is necessarily true for technical assistance, but for non-technical assistance the result depends on whether the change is viewed as being temporary or permanent. In addition, given our modeling assumptions, we expect to find a more significant effect of foreign aid on income growth at shorter time horizons. Only a permanent increase in technical assistance is expected to have a long-term effect on capital and income.

Despite what the model predicts for TA, Riddell (2007) refers to "a growing consensus - not least among many leading official donors - that TA, as traditionally given, has largely been a failure." However, Riddell also notes that surprisingly enough there is little evidence of studies that have assessed the results and impact of TA. The assessment that TA has mainly been a failure stems from two kinds of observations among others: First, the costs of providing TA have always been very high. Riddell reports that for example the yearly costs of employing a foreign consultant amounted to about $\$ 150,000$ in the early 80 s. Today, this amount is probably the double. A second problem associated with TA is duplication of activities which has arisen because donors failed to consult with each other. For example, Riddell (2007, p. 205) claims that "it was not uncommon in the past, and still not unknown today, for long-term consultants, working in a ministry to discover other consultants, located even along the same corridor, funded by other donors to do work overlapping with their own." In the next section we will provide empirical evidence in support of a positive relationship between TA and income growth, and we will 
address the possibility of overlap by including donor fragmentation of TA into our regression analysis.

\section{Aid and Growth: Empirical Analysis}

The model developed previously distinguishes between technical assistance and non-technical assistance and shows that TA enhances economic growth at least in the short run no matter whether this form of aid is perceived as being permanent or temporary. In contrast, NTA does not increase income growth rates when perceived as being permanent.

In order to test these predictions, we separate between these two forms of aid and estimate the following model using a sample of 105 countries: ${ }^{16}$

$$
\begin{aligned}
\frac{y_{i, t}-y_{i, t-1}}{T}=b_{0} & +b_{1} y_{i, t-1}+b_{2} T A_{i, t}+b_{3} N T A_{i, t}+\boldsymbol{b}_{\mathbf{4}} \boldsymbol{X}_{i, t}^{\prime} \\
& +b_{5} F_{i, t}+b_{6} F_{i, t} \times T A_{i, t}+\phi_{i}+\varphi_{t}+\epsilon_{i, t}
\end{aligned}
$$

where the subscript $i$ indexes countries, $t$ indexes periods, and $T$ measures period length. For our main result we use data between 1970 and 2004 and divide this length into eight 4-year and one 3-year period indexed by $t \in\{1, \ldots, 9\}$. We use 4-year periods because they have been used elsewhere (for example, Burnside and Dollar (2000)). We use period averages to estimate the impact of foreign aid on growth. This procedure is done to account for business cycle movements. ${ }^{17}$

The dependent variable is the average annual growth rate of real per capita GDP during period $t . y_{i, t-1}$ is the logarithm of real per capita GDP in the last year of period $t-1$. $T A_{i t}$ and $N T A_{i, t}$ are the average per capita levels during period $t$ for technical and non-technical assistance respectively. The aid data is from the OECD. TA is measured using the data series "technical cooperation." For NTA we focus on current and actual transfers, thereby following Roodman (2006). We exclude all debt forgiveness grants and capitalized interest, none of which involves actual movement of money. ${ }^{18}$ In addition, we exclude food and emergency aid from our measure since we believe that these forms of aid are not directly intended

\footnotetext{
${ }^{16} \mathrm{~A}$ list of the countries in the sample is provided in Table 7 in the Appendix. We include all countries in our sample for which data is available.

${ }^{17}$ Note, however, that in Table 4 we present results when estimating (20) with varying definitions of period length.

${ }^{18}$ Debt forgiveness would not affect any economic decisions if it was anticipated or if it was given because the recipient is unable to service the debt.
} 
for "development." Subtracting TA from this measure then yields our measure for NTA. ${ }^{19}$ Both of our aid measures, TA and NTA, are PPP adjusted.

The vector $\boldsymbol{X}_{i, t}$ is a vector of control variables that affect the steady state of country $i$. Our strategy for selecting the appropriate controls is to adopt a specification that is close to the one typically used in the aid effectiveness literature (e.g. Burnside and Dollar, 2000; Rajan and Subramanian, 2008). In particular, we include policy variables such as openness, M2/GDP, inflation, and budget balance divided by GDP. We also include life expectancy and the average number of revolutions in a given period defined as any forced attempted or succeeded change in the top of the government. Data sources are explained in Table 8 in the Appendix. In contrast to the typical aid effectiveness literature, we also include a control for the investment rate. We have theoretical reasons to do so because the investment rate is an important control for the steady state of an economy. In Column (4) in Table 3 , however, we report results without the investment rate and we show that similar results are obtained.

The variable $F_{i, t}$ measures the average donor fragmentation of recipient country $i$ in period $t$. The fragmentation index is constructed by calculating a Herfindahl index of donor concentration, which ranges from 0 to 1 . This index is then subtracted from 1 and multiplied by 100. The value of donor fragmentation of zero indicates completely unfragmented aid (i.e. one donor in a given country). The fragmentation measure increases in the number of donors or with equality of aid shares. We argued in the introduction that if the technology for the disbursement of TA exhibits increasing returns to scale, then less fragmented TA will have a larger impact on growth rates than more fragmented TA. Furthermore, we indicated that donor duplication is a well known problem associated with TA (Riddell, 2007). We believe that this argument does not apply to foreign aid that is fungible and affects the resource constraint of a country. For example, we do not expect the effectiveness of NTA to depend on donor fragmentation. In order to test the impact of donor fragmentation on aid effectiveness, we include an interaction term of TA and donor fragmentation in our main specification. In Table 2 we report estimation results when we also include an interaction term for NTA. The evidence reported there seems to support our claim that there is no interaction effect between donor fragmentation and NTA.

In (20), the partial impact of technical aid on growth equals $b_{2}+b_{6} \times F$. In addition, the standard error of interest now is given by

$$
\hat{\sigma}_{\frac{\partial y}{\partial T A}}=\sqrt{\operatorname{var}\left(\hat{b}_{2}\right)+F \operatorname{var}\left(\hat{b}_{6}\right)+2 F \operatorname{cov}\left(\hat{b}_{2}, \hat{b}_{6}\right)} .
$$

\footnotetext{
${ }^{19}$ Our aid measure NTA is derived from aid data reported by the OECD as follows: NTA= Total Grants-Debt Forgiveness Grants+ODA loans extended-Reorganized Debt-Emergency AidDevelopment Food Aid-Technical Cooperation.
} 
It is important to point out that the standard error now depends on the level of donor fragmentation, $F$. In particular, note that in case the estimates of $b_{2}$ and $b_{6}$ are not statistically significant separately, they may nevertheless be significant jointly, since $\operatorname{cov}\left(\hat{b}_{2}, \hat{b}_{6}\right)$ can be negative. ${ }^{20}$ We hypothesize that $b_{6}$ is negative so that the effectiveness of aid decreases as donor fragmentation increases.

Finally $\phi_{i}$ and $\varphi_{t}$ are country and time fixed effects. We use a country fixed effect to properly control for unobserved time invariant variables that may be correlated with some of the independent variables. In particular, we do not need to control for institutions, where only imperfect measures are available. Glaeser, La Porta, Lopez-de Silanes, and Shleifer (2004) provides a discussion of the institutional measures used in the growth literature which highlights their limitations. By using fixed effects, we avoid these limitations. ${ }^{21}$ Furthermore, fixed effects will also control for other permanent factors such as culture and initial level of technology.

Using a fixed effect estimator (FE) for equation (20), however, raises econometric issues. First, a fixed effect estimator yields consistent estimates if the so called "strict exogeneity" assumption holds. This assumption states that $e_{i, t}$ is not correlated with any other future, current, and past right-hand side variable in (20). In a model with a lagged depended variable, the strict exogeneity assumption is necessarily violated (Woolbridge, 2002, p. 255). Thus, estimates using a fixed-effect estimator in this setting are biased. Monte Carlo simulations, however, show that the bias on the lagged dependent variable can be significant, while it tends to be minor for other right-hand side variables (Judson and Owen, 1996). This would be true for foreign aid. There are estimators that are able to address the problem of unobserved country fixed effects which do not require the strict exogeneity assumption. Building on Arellano and Bond (1991), Blundell and Bond (1998) developed a system estimator (GMM(sys)) that allows $e_{i, t}$ to be correlated with future values of the other right-hand side variables in (20) (but not with current and past values) which is consistent with the generalized method-of-moments (GMM). ${ }^{22}$ This estimator uses lagged level variables as instruments for differences and lagged differences as instruments for level variables. Note that this instrumentation strategy can be implemented for any right hand side variable that one suspects to be en-

\footnotetext{
${ }^{20}$ Most of the critical discussion of the policy interaction term in Burnside and Dollar (2000) focusses on the significance of the interaction term itself (see for example Easterly (2003) and Easterly, Levine, and Roodman (2004)). We believe this is misleading. For an assessment of aid effectiveness, one needs to focus on the point estimates and standard errors pointed out above. Brambor, Clark, and Golder (2006) provide a useful discussion of how to correctly interpret interaction terms.

${ }^{21}$ Note also that data on institutions is often available for a limited set of (developing) countries and typically the data does not got far back.

${ }^{22}$ We use $x$ tabond 2 in Stata for our regressions. For a detailed description and for advice on how to use this command see Roodman (2009).
} 
dogenous. For example, if foreign aid is given because of the "need" of a recipient country as its economy is under-performing, then treating aid as exogenous introduces a downward bias. For this reason we treat our aid variables as endogenous variables where lagged level variables serve as an instrument for first differences and lagged differences serve as an instrument for level variables. Note that in the results reported we use only one lag, since using more lags can easily lead to weak instrument problems. ${ }^{23}$

Column (4) in Table 1 reports our main result. Table 1 also includes ordinary least square (OLS), fixed-effect (FE), and GMM difference results for comparison reasons. Since system GMM corrects for the bias introduced because of the inclusion of initial GDP per capita as a lagged dependent variable, the expectation is that the coefficient for initial GDP per capita is somewhere between the coefficient estimated using OLS and FE. This prediction is confirmed in Table 1. In addition, the point estimates on TA increase when comparing OLS and FE results with the GMM difference and GMM system results. Difference and system GMM uses lagged aid values as instruments to address potential problems of endogeneity. Again, this result is expected since treating aid as exogenous likely introduces a downward bias. In the following tables, we use system GMM for all estimations.

The results shown in Column (4) of Table 1 show a strong positive impact of TA on income growth. The result suggest that increasing TA pc by 10 dollars will increase the growth rate by 0.6 percentage points if donor fragmentation is zero. Note that in the sample, average TA pc is equal to about $\$ 30$. To give 0.7 percent of GNP as official development assistance is often discussed as a reasonable target among policy makers. Reaching this target means that aid would more than triplicate from 0.2 percent of GNP in 2002. Accordingly, increasing TA by 50 dollars will increase growth rates by about 3 percentage points if donor fragmentation is zero. The impact of TA pc on growth, however, declines as donor fragmentation increases. For the typical developing country, donor fragmentation is quite high. In our sample, the average donor fragmentation index for TA equals $65 \%$.

The coefficient for the interaction term between donor fragmentation and TA is significant and negative as expected. For example, with a donor fragmentation index of $50 \%$, a 50 dollar increase in per capita TA increases the growth rate by only 0.75 percentage points as compared to the 3 percentage points if donor fragmentation is zero. Furthermore, for the country with an average donor fragmentation, the partial impact of TA pc on income growth is zero. Thus, our results suggest a strong interaction effect between aid effectiveness and donor fragmentation. Using (21),

\footnotetext{
${ }^{23}$ We, hereby, follow Roodman (2009), who cautions from using too many instruments. Note, however, that increasing the number of lags does not affect our result. We obtain similar results no matter the exact lag structure we use.
} 
Annen and Kosempel: Foreign Aid, Donor Fragmentation, and Economic Growth

Table 1: Foreign Aid and Growth: Main Result

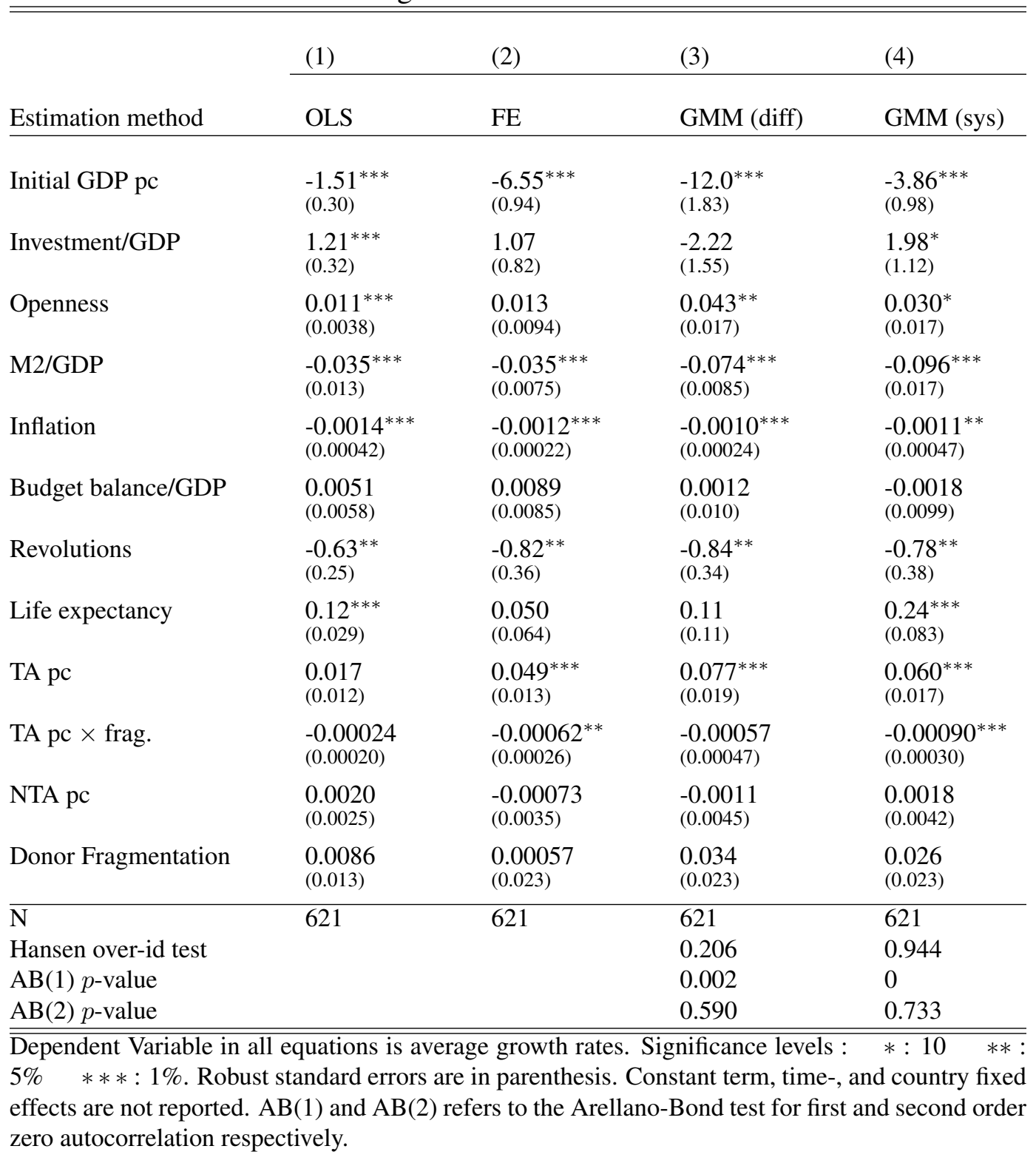

Figure 2 plots a 95\% confidence interval for the partial impact of TA on growth for fragmentation levels between 0 and 100 based on the estimation results reported in Column (4), Table 1. This figure confirms our hypothesis that the partial impact of TA on growth decreases with an increasing level of fragmentation. For countries with a donor fragmentation below $51 \%$ we find a positive and statistically significant impact of TA on growth at the $5 \%$ level. For levels of donor fragmentation 
The B.E. Journal of Macroeconomics, Vol. 9 [2009], Iss. 1 (Contributions), Art. 33

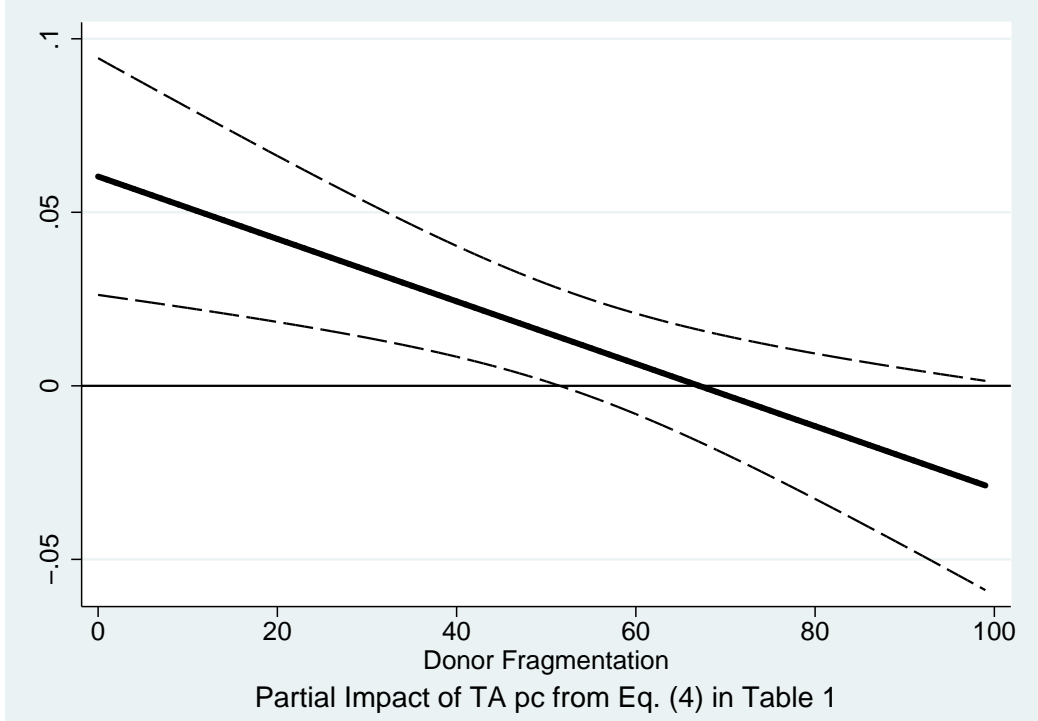

Figure 2: 95\% Confidence Interval of Partial Impact of TA pc

exceeding $66 \%, b_{2}+b_{6} \times F$ becomes negative but remains insignificant.

In contrast to TA, the evidence suggests that there is no significant positive nor negative impact of NTA on growth. The coefficient for NTA is not significant. There may be at least two reasons for this finding: First, the model introduced earlier suggests that if NTA is perceived as being permanent then the income growth rate does not change as a result of an influx of NTA. ${ }^{24}$ NTA is consumed instead of being invested. Boone (1996) and more recently Chatterjee, Giuliano, and Ilker (2007) provide evidence that suggests that most of foreign aid is consumed rather than invested. The second reason for the finding may be that NTA is still a residual measure of aid. It may include some forms of aid that are not intended to foster economic development, and therefore a further disaggregation of this aid measure is needed in order to get a better understanding of the impact of NTA on growth.

Table 1 furthermore confirms other predictions of the neoclassical growth model introduced earlier. The countries in the sample exhibit conditional convergence (since the point estimates of initial GDP are negative), with an annual convergence rate of $4.2 \%$ for System GMM. This estimate is well within the rates observed in the literature. ${ }^{25}$ We also find that the investment rate positively affects economic

\footnotetext{
${ }^{24}$ Recall that in the model the effect that a change in NTA has on income growth depends on whether it is perceived as being permanent or temporay. Since we cannot observe from the data how changes in aid levels are perceived, then pooling this shocks and estimating an average effect means we should find smaller effects for NTA than TA.

${ }^{25}$ See Barro and Sala-i Martin (2004) for a survey of the empirical growth literature.
} 
growth. The estimate is significant in Column (4), although only at the $10 \%$ level. Openness has the expected sign and is significant at the $10 \%$ level. In contrast, budget balance has not the expected sign and is not significant. Finally, the remaining control variables are revolutions and life expectancy, and they have the expected sign and are significant.

\section{Sensitivity Analysis}

In this section we analyze how sensitive the results presented in Column (4) of Table 1 are to various changes to the estimation procedure. First, we analyze how our main result is affected by changing the specification of our regression model. Second, we analyze our empirical model when changing the definition of period length. In this subsection, we include a cross-sectional analysis looking at the time horizon between 1970 and 2004. Finally, we test the robustness of our main result when normalizing aid differently. Particularly, we compare the results when using TA divided by GDP instead of TA per capita as done in the analysis so far.

\subsection{Sensitivity to Model Specification}

In Tables 2 and 3 we analyze the sensitivity of our result to the exact specification of the empirical model. In Table 2 we vary the combination of the two forms of aid and their respective interaction terms included in the model. One reason for this analysis is that having more than one form of aid in a regression raises concerns about multi-collinearity. Columns (1) and (2) in Table 2 include only TA and TA interacted with fragmentation respectively, while columns (3) and (4) repeat this analysis for NTA. Finally, in column (5) we run a regression that includes TA and NTA and an interaction term for both of them. This table shows that the coefficient for TA pc is always positive and significant while the coefficient for NTA pc is not. TA pc is positive and significant (although only at the 10 percent level) when the interaction term with donor fragmentation is excluded. The interaction term for TA is also highly significant when NTA is excluded. In column (5) the interaction term for TA is not significant but a confidence interval plot for this equation would look similar to the one presented in Figure 2. The interaction term for NTA has a negative sign but is not significant. When plotting a confidence interval for the partial impact of NTA on growth similar to the one shown in Figure 2, it would show no significant impact of NTA on growth no matter the fragmentation level.

We can conclude that our result is robust no matter whether we include an interaction term for NTA or exclude NTA altogether. TA has a positive and significant 
The B.E. Journal of Macroeconomics, Vol. 9 [2009], Iss. 1 (Contributions), Art. 33

Table 2: Sensitivity to the Inclusion of Different Forms of Aid

\begin{tabular}{|c|c|c|c|c|c|}
\hline & $(1)$ & $(2)$ & (3) & $(4)$ & $(5)$ \\
\hline Initial GDP pc & $\begin{array}{l}-2.69^{* * *} \\
(0.81)\end{array}$ & $\begin{array}{l}-3.75^{* * *} \\
(0.97)\end{array}$ & $\begin{array}{l}-2.61^{* *} \\
(1.02)\end{array}$ & $\begin{array}{l}-2.47^{* * *} \\
(0.91)\end{array}$ & $\begin{array}{l}-3.13^{* * *} \\
(0.89)\end{array}$ \\
\hline Investment/GDP & $\begin{array}{l}1.84 \\
(1.17)\end{array}$ & $\begin{array}{l}1.77 \\
(1.19)\end{array}$ & $\begin{array}{l}2.11^{*} \\
(1.19)\end{array}$ & $\begin{array}{l}2.32^{* *} \\
(1.17)\end{array}$ & $\begin{array}{l}2.39^{* *} \\
(1.07)\end{array}$ \\
\hline Openness & $\begin{array}{l}0.027^{*} \\
(0.015)\end{array}$ & $\begin{array}{l}0.028^{*} \\
(0.016)\end{array}$ & $\begin{array}{l}0.025^{*} \\
(0.015)\end{array}$ & $\begin{array}{l}0.020 \\
(0.014)\end{array}$ & $\begin{array}{l}0.021 \\
(0.015)\end{array}$ \\
\hline M2/GDP & $\begin{array}{l}-0.089^{* * *} \\
(0.016)\end{array}$ & $\begin{array}{l}-0.095^{* * *} \\
(0.016)\end{array}$ & $\begin{array}{l}-0.090^{* * *} \\
(0.017)\end{array}$ & $\begin{array}{l}-0.068^{* * *} \\
(0.010)\end{array}$ & $\begin{array}{l}-0.065^{* * *} \\
(0.011)\end{array}$ \\
\hline Inflation & $\begin{array}{l}-0.0011^{* *} \\
(0.00052)\end{array}$ & $\begin{array}{l}-0.0011^{* *} \\
(0.00049)\end{array}$ & $\begin{array}{l}-0.00097^{*} \\
(0.00051)\end{array}$ & $\begin{array}{l}-0.00080^{*} \\
(0.00046)\end{array}$ & $\begin{array}{l}-0.00080^{*} \\
(0.00042)\end{array}$ \\
\hline Budget balance/GDP & $\begin{array}{l}-0.016 \\
(0.015)\end{array}$ & $\begin{array}{l}-0.017 \\
(0.016)\end{array}$ & $\begin{array}{l}0.0068 \\
(0.012)\end{array}$ & $\begin{array}{l}-0.00058 \\
(0.0100)\end{array}$ & $\begin{array}{l}-0.0038 \\
(0.011)\end{array}$ \\
\hline Revolutions & $\begin{array}{l}-0.72^{*} \\
(0.38)\end{array}$ & $\begin{array}{l}-0.70^{*} \\
(0.38)\end{array}$ & $\begin{array}{l}-0.77^{* *} \\
(0.39)\end{array}$ & $\begin{array}{l}-0.91^{* *} \\
(0.37)\end{array}$ & $\begin{array}{l}-0.87^{* *} \\
(0.38)\end{array}$ \\
\hline Life expectancy & $\begin{array}{l}0.19^{* *} \\
(0.083)\end{array}$ & $\begin{array}{l}0.26^{* * *} \\
(0.087)\end{array}$ & $\begin{array}{l}0.21^{* *} \\
(0.082)\end{array}$ & $\begin{array}{l}0.21^{* * *} \\
(0.078)\end{array}$ & $\begin{array}{l}0.20^{* *} \\
(0.078)\end{array}$ \\
\hline TA pc & $\begin{array}{l}0.019^{*} \\
(0.011)\end{array}$ & $\begin{array}{l}0.060^{* * *} \\
(0.016)\end{array}$ & & & $\begin{array}{l}0.048^{* * *} \\
(0.017)\end{array}$ \\
\hline TA pc $\times$ frag. & & $\begin{array}{l}-0.00084^{* * *} \\
(0.00029)\end{array}$ & & & $\begin{array}{l}-0.00049 \\
(0.00030)\end{array}$ \\
\hline NTA pc & & & $\begin{array}{l}0.0066 \\
(0.0062)\end{array}$ & $\begin{array}{l}0.012 \\
(0.0094)\end{array}$ & $\begin{array}{l}0.0069 \\
(0.0062)\end{array}$ \\
\hline NTA pc $\times$ frag. & & & & $\begin{array}{l}-0.00011 \\
(0.00015)\end{array}$ & $\begin{array}{l}-0.00019 \\
(0.00013)\end{array}$ \\
\hline Donor Fragmentation & & $\begin{array}{l}0.026 \\
(0.026)\end{array}$ & & & $\begin{array}{l}0.0078 \\
(0.024)\end{array}$ \\
\hline Donor Fragmentation NTA & & & & $\begin{array}{l}0.00046 \\
(0.00039)\end{array}$ & $\begin{array}{l}0.00055 \\
(0.00039)\end{array}$ \\
\hline $\mathrm{N}$ & 621 & 621 & 621 & 616 & 616 \\
\hline Hansen over-id test & 0.263 & 0.418 & 0.286 & 0.718 & 0.999 \\
\hline $\mathrm{AB}(1) p$-value & 0 & 0 & 0 & 0 & 0 \\
\hline $\mathrm{AB}(2) p$-value & 0.702 & 0.794 & 0.576 & 0.631 & 0.838 \\
\hline
\end{tabular}

$\overline{\bar{D}}$ Dependent Variable in all equations is average growth rates. Significance levels : $*: 10 \quad * *$ : $5 \% \quad * * *: 1 \%$. All estimations use the system GMM estimator. Robust standard errors are in parenthesis. Constant term and time fixed effects are not reported. $\mathrm{AB}(1)$ and $\mathrm{AB}(2)$ refers to the Arellano-Bond test for first and second order zero autocorrelation respectively.

impact on growth as long as TA is not too fragmented. Table 2 also confirms our main result related to NTA: This form of aid has no significant impact on growth.

In Table 3 we analyze how our result changes when changing the set of control variables included in the regression model. It should be noted, however, that our 
specification includes all controls that in the empirical literature on aid effectiveness are considered to be important. Note also that in this table and in the following ones we no longer include NTA for the sake of having a more parsimonious specification. The main objective of these tables is to analyze the robustness of our result with respect to TA pc. In Column (2) we exclude life-expectancy and revolutions; in Column (3) we exclude all policy variables, and finally in Column (4) we exclude the investment rate. This table suggests that our results are robust to these changes of the empirical specification. In all columns, the magnitudes of the coefficients for TA pc and its interaction term remain essentially the same as compared to our main specification, and all the coefficients remain statistically significant. We can conclude that our result is robust to the exact specification of the regression model used.

\subsection{Sensitivity to the Choice of Period Length}

Table 4 analyzes how the results are affected when altering the definition of period length. Period length yields insights into how long it takes for aid to have an impact on growth. One may hope for aid to have a long term impact (e.g. Rajan and Subramanian, 2008), but it is ultimately an empirical question of whether aid impacts growth rates in the short- or in the long run. Our theoretical model shows that if TA pc is perceived as being permanent then it will have a positive and permanent effect on income. In contrast, if TA pc is being perceive as being temporary then it increases growth rates only in the short run. Our main result suggests that TA pc increases growth rates, at least in the short run. Table 4 shows that as we extend the period length, our results are fairly robust to this alteration. The coefficient for TA pc is positive and significant in all columns, except in Column (4) where we analyze 10 year periods. The interaction term is negative and significant in all columns. Thus, we find a strong interaction effect between TA effectiveness and donor fragmentation no matter the period definition we use. In all estimations, the message is the same: A high level of donor fragmentation significantly reduces the impact of TA pc on income growth.

We obtain a similar result when abandoning panel regressions and switching to cross-sectional regressions. In this way we can test for the partial impact of TA pc on income growth for the time horizon between 1970 and 2004. However, the drawback of cross-sectional regressions is that we are no longer able to control for unobserved heterogeneity. In these regressions we include some additional controls such as institutional quality (ICRG), ethnic fractionalization, and geography such as the percentage of tropical area and an Sub-saharan Africa dummy and an East Asia dummy. Table 5 shows the cross-sectional results. We present OLS and 2 SLS results. For the 2 SLS result reported in Column (2), we use a similar instru- 
The B.E. Journal of Macroeconomics, Vol. 9 [2009], Iss. 1 (Contributions), Art. 33

Table 3: Sensitivity to the Choice of Control Variables

\begin{tabular}{|c|c|c|c|c|}
\hline & (1) & (2) & (3) & (4) \\
\hline Initial GDP pc & $\begin{array}{l}-3.75^{* * *} \\
(0.97)\end{array}$ & $\begin{array}{l}-1.78^{* *} \\
(0.73)\end{array}$ & $\begin{array}{l}-2.84^{* * *} \\
(0.90)\end{array}$ & $\begin{array}{l}-3.61^{* * *} \\
(1.26)\end{array}$ \\
\hline Investment/GDP & $\begin{array}{l}1.77 \\
(1.19)\end{array}$ & $\begin{array}{l}3.50^{* * *} \\
(1.03)\end{array}$ & $\begin{array}{l}3.37^{* * *} \\
(0.79)\end{array}$ & \\
\hline Openness & $\begin{array}{l}0.028^{*} \\
(0.016)\end{array}$ & $\begin{array}{l}0.015 \\
(0.016)\end{array}$ & & $\begin{array}{l}0.041^{* * *} \\
(0.014)\end{array}$ \\
\hline M2/GDP & $\begin{array}{l}-0.095^{* * *} \\
(0.016)\end{array}$ & $\begin{array}{l}-0.098^{* * *} \\
(0.017)\end{array}$ & & $\begin{array}{l}-0.11^{* * *} \\
(0.020)\end{array}$ \\
\hline Inflation & $\begin{array}{l}-0.0011^{* *} \\
(0.00049)\end{array}$ & $\begin{array}{l}-0.0013^{* *} \\
(0.00057)\end{array}$ & & $\begin{array}{l}-0.0012^{* *} \\
(0.00050)\end{array}$ \\
\hline Budget balance/GDP & $\begin{array}{l}-0.017 \\
(0.016)\end{array}$ & $\begin{array}{l}-0.015 \\
(0.018)\end{array}$ & & $\begin{array}{l}-0.012 \\
(0.010)\end{array}$ \\
\hline Revolutions & $\begin{array}{l}-0.70^{*} \\
(0.38)\end{array}$ & & $\begin{array}{l}-1.05^{* * *} \\
(0.38)\end{array}$ & $\begin{array}{l}-0.79^{* *} \\
(0.39)\end{array}$ \\
\hline Life expectancy & $\begin{array}{l}0.26^{* * *} \\
(0.087)\end{array}$ & & $\begin{array}{l}0.19^{* *} \\
(0.088)\end{array}$ & $\begin{array}{l}0.29^{* * *} \\
(0.081)\end{array}$ \\
\hline TA pc & $\begin{array}{l}0.060^{* * *} \\
(0.016)\end{array}$ & $\begin{array}{l}0.045^{\text {*** }} \\
(0.014)\end{array}$ & $\begin{array}{l}0.063^{\text {*** }} \\
(0.016)\end{array}$ & $\begin{array}{l}0.050^{* *} \\
(0.020)\end{array}$ \\
\hline TA pc $\times$ frag. & $\begin{array}{l}-0.00084^{* * *} \\
(0.00029)\end{array}$ & $\begin{array}{l}-0.00046^{*} \\
(0.00026)\end{array}$ & $\begin{array}{l}-0.00081^{* * *} \\
(0.00030)\end{array}$ & $\begin{array}{l}-0.00074^{* *} \\
(0.00034)\end{array}$ \\
\hline Donor Fragmentation & $\begin{array}{l}0.026 \\
(0.026)\end{array}$ & $\begin{array}{l}0.011 \\
(0.028)\end{array}$ & $\begin{array}{l}0.010 \\
(0.028)\end{array}$ & $\begin{array}{l}0.029 \\
(0.028)\end{array}$ \\
\hline$\overline{\mathrm{N}}$ & 621 & 621 & 621 & 621 \\
\hline Hansen Over-id test & 0.418 & 0.472 & 0.363 & 0.146 \\
\hline $\mathrm{AB}(1) p$-value & 0 & 0 & 0 & 0 \\
\hline $\mathrm{AB}(2) p$-value & 0.794 & 0.804 & 0.852 & 0.796 \\
\hline
\end{tabular}

mentation strategy than the one adopted in Rajan and Subramanian (2008). That is we use information on the colonial past, common language, and population ratios (as a proxy for donor influence) to predict TA receipts using the dyadic data set of donor-recipient pairs. ${ }^{26}$ The estimation results for the exogenous variation of TA pc by donor across recipients is reported in Table 9 in the Appendix. We then aggregate donor-recipient aid flows to get one observation of predicted TA pc per recipient. Predicted TA pc is then used as an instrument for actual TA pc. The specification

\footnotetext{
${ }^{26}$ The only difference to Rajan and Subramanian (2008) is that we do not use a dummy for countries that are currently in a colonial relationship. Our sample does not include such a country.
} 
Annen and Kosempel: Foreign Aid, Donor Fragmentation, and Economic Growth

Table 4: Sensitivity to the Choice of Period Length

\begin{tabular}{|c|c|c|c|c|}
\hline \multirow[b]{2}{*}{ Period Interval } & $(1)$ & $(2)$ & (3) & $(4)$ \\
\hline & 5-years & 6-years & 8-years & 10-years \\
\hline Initial GDP pc & $\begin{array}{l}-5.66^{* * *} \\
(1.47)\end{array}$ & $\begin{array}{l}-3.49^{* * *} \\
(1.01)\end{array}$ & $\begin{array}{l}-2.95^{* * *} \\
(1.02)\end{array}$ & $\begin{array}{l}-1.62^{* *} \\
(0.81)\end{array}$ \\
\hline Investment/GDP & $\begin{array}{l}0.78 \\
(1.05)\end{array}$ & $\begin{array}{l}1.43 \\
(0.97)\end{array}$ & $\begin{array}{l}1.45^{*} \\
(0.79)\end{array}$ & $\begin{array}{l}1.55^{*} \\
(0.87)\end{array}$ \\
\hline Openness & $\begin{array}{l}0.025^{*} \\
(0.013)\end{array}$ & $\begin{array}{l}0.026^{* *} \\
(0.012)\end{array}$ & $\begin{array}{l}0.017 \\
(0.011)\end{array}$ & $\begin{array}{l}0.019^{*} \\
(0.011)\end{array}$ \\
\hline M2/GDP & $\begin{array}{l}-0.042 \\
(0.042)\end{array}$ & $\begin{array}{l}-0.092^{* * *} \\
(0.020)\end{array}$ & $\begin{array}{l}0.00013 \\
(0.014)\end{array}$ & $\begin{array}{l}0.011 \\
(0.0094)\end{array}$ \\
\hline Inflation & $\begin{array}{l}-0.00099^{* * *} \\
(0.00020)\end{array}$ & $\begin{array}{l}-0.0012^{* *} \\
(0.00053)\end{array}$ & $\begin{array}{l}-0.00085^{* *} \\
(0.00038)\end{array}$ & $\begin{array}{l}-0.0012^{* * *} \\
(0.00037)\end{array}$ \\
\hline Budget balance/GDP & $\begin{array}{l}0.0036 \\
(0.011)\end{array}$ & $\begin{array}{l}0.012^{* * *} \\
(0.0042)\end{array}$ & $\begin{array}{l}0.050^{* * *} \\
(0.017)\end{array}$ & $\begin{array}{l}0.37 \\
(0.64)\end{array}$ \\
\hline Revolutions & $\begin{array}{l}-1.21^{* * *} \\
(0.45)\end{array}$ & $\begin{array}{l}-0.47 \\
(0.41)\end{array}$ & $\begin{array}{l}-0.59 \\
(0.47)\end{array}$ & $\begin{array}{l}-0.15 \\
(0.36)\end{array}$ \\
\hline Life expectancy & $\begin{array}{l}0.34^{* * *} \\
(0.086)\end{array}$ & $\begin{array}{l}0.22^{* * *} \\
(0.078)\end{array}$ & $\begin{array}{l}0.20^{* * *} \\
(0.055)\end{array}$ & $\begin{array}{l}0.11^{* *} \\
(0.054)\end{array}$ \\
\hline TA pc & $\begin{array}{l}0.059^{* * *} \\
(0.019)\end{array}$ & $\begin{array}{l}0.049^{* * *} \\
(0.017)\end{array}$ & $\begin{array}{l}0.054^{* *} \\
(0.027)\end{array}$ & $\begin{array}{l}0.026 \\
(0.020)\end{array}$ \\
\hline TA pc $\times$ frag. & $\begin{array}{l}-0.0011^{* * *} \\
(0.00035)\end{array}$ & $\begin{array}{l}-0.00081^{* * *} \\
(0.00030)\end{array}$ & $\begin{array}{l}-0.00095^{* *} \\
(0.00042)\end{array}$ & $\begin{array}{l}-0.00067^{* *} \\
(0.00032)\end{array}$ \\
\hline Donor Fragmentation & $\begin{array}{l}0.041^{*} \\
(0.025)\end{array}$ & $\begin{array}{l}0.042^{* *} \\
(0.021)\end{array}$ & $\begin{array}{l}0.046 \\
(0.028)\end{array}$ & $\begin{array}{l}0.016 \\
(0.017)\end{array}$ \\
\hline $\mathrm{N}$ & 498 & 435 & 300 & 289 \\
\hline Hansen over-id test & 0.300 & 0.263 & 0.278 & 0.479 \\
\hline $\mathrm{AB}(1) p$-value & 0 & 0 & 0.003 & 0.001 \\
\hline $\mathrm{AB}(2) p$-value & 0.229 & 0.046 & 0.168 & 0.315 \\
\hline $\begin{array}{l}\text { Dependent Variable in } \\
: 5 \% \quad * * *: 1 \% \text {. } \\
\text { in parenthesis. Consta } \\
\text { refers to the Arellano- }\end{array}$ & $\begin{array}{l}\text { uations is av } \\
\text { imations use }\end{array}$ & $\begin{array}{l}\text { growth rates. } \\
\text { stem GMM } \\
\text { y fixed effec } \\
\text { nd order zer }\end{array}$ & $\begin{array}{l}\text { icance leve } \\
\text { tor. Robust }\end{array}$ & $\begin{array}{l}*: 10 \quad * * \\
\text { ard errors are } \\
\text { 1) and } \mathrm{AB}(2) \\
\text { ively. }\end{array}$ \\
\hline
\end{tabular}

reported in Column (2) in Table 5 is the one that is closest to the specification reported in Rajan and Subramanian (2008). In the specification reported in Column (3) we add the Sub-saharan Africa and the East Asia dummy variables as additional controls as done in Burnside and Dollar (2000). In this latter specification we find a similar result than in the panel estimations. The coefficient for TA pc is positive and significant and the interaction term is negative and again significant. In Column (4) we add "democracy" from Freedom house as an additional instrument so that 
The B.E. Journal of Macroeconomics, Vol. 9 [2009], Iss. 1 (Contributions), Art. 33

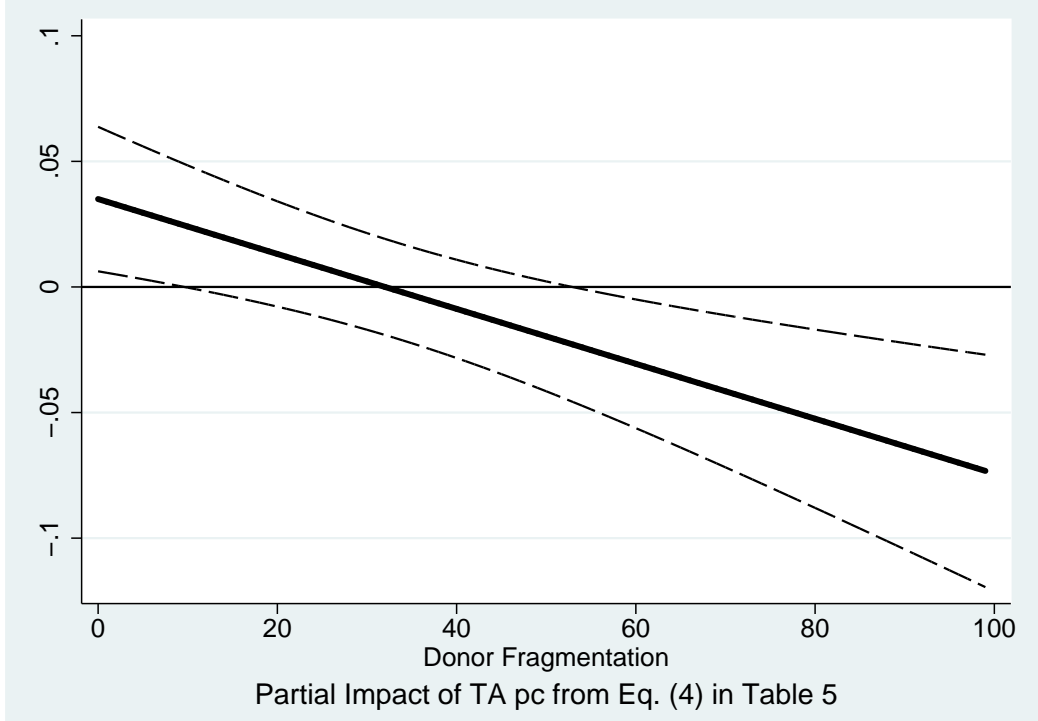

Figure 3: 95\% Confidence Interval of Partial Impact of TA pc

we can run a Hansen over-identification test. We fail to reject the null hypothesis that our instruments are exogenous, suggesting that our predicted aid variable is a valid instrument.

In order to compare this result with our main result we plot the $95 \%$ confidence interval in Figure 3. We find a positive and significant positive impact of TA pc on income growth provided that donor fragmentation is low enough - similar than in Figure 2. In contrast to the panel result plotted in Figure 2, we find that TA pc can actually adversely affect income growth if donor fragmentation is high. This evidence suggests that TA pc positively affects economic performance in the shortand long-run provided that donor fragmentation is low enough. In contrast, if donor fragmentation is high, we find no significant impact on income growth in the shortrun but a negative impact on income growth in the long-run.

In conclusion, we find evidence that TA pc interacts negatively with donor fragmentation. The partial impact of TA pc on income growth declines as donor fragmentation increases. We obtain this result using a range of different estimation procedures. When we vary the period length, we can learn something about the short- and long-run impact of TA pc. Here, we find a positive and significant effect of TA pc on income growth provided that donor fragmentation is sufficiently low in the short- and long-run. This result goes a long with the model's prediction presented earlier for the case when TA is perceived as being permanent. The reported evidence, in addition, suggests that TA pc may lower growth rates when donor frag- 
Annen and Kosempel: Foreign Aid, Donor Fragmentation, and Economic Growth

Table 5: Cross-section 1970-2004

\begin{tabular}{|c|c|c|c|c|}
\hline \multirow[b]{2}{*}{ Estimation method } & \multirow{2}{*}{$\begin{array}{l}(1) \\
\text { OLS }\end{array}$} & \multirow{2}{*}{$\begin{array}{l}(2) \\
2 \text { SLS }\end{array}$} & \multirow{2}{*}{$\begin{array}{l}(3) \\
2 S L S\end{array}$} & \multirow{2}{*}{$\begin{array}{l}(4) \\
2 S L S\end{array}$} \\
\hline & & & & \\
\hline Initial GDP pc & $\begin{array}{l}-1.25^{* * *} \\
(0.22)\end{array}$ & $\begin{array}{l}-1.25^{* * *} \\
(0.20)\end{array}$ & $\begin{array}{l}-1.22^{* * *} \\
(0.18)\end{array}$ & $\begin{array}{l}-1.22^{* * *} \\
(0.18)\end{array}$ \\
\hline Investment/GDP & $\begin{array}{l}1.05^{* * *} \\
(0.31)\end{array}$ & $\begin{array}{l}1.06^{* * *} \\
(0.30)\end{array}$ & $\begin{array}{l}0.69^{* *} \\
(0.35)\end{array}$ & $\begin{array}{l}0.68^{* *} \\
(0.34)\end{array}$ \\
\hline Openness (initial) & $\begin{array}{l}0.0034^{*} \\
(0.0019)\end{array}$ & $\begin{array}{l}0.0045^{* * *} \\
(0.0016)\end{array}$ & $\begin{array}{l}0.0049^{* * *} \\
(0.0014)\end{array}$ & $\begin{array}{l}0.0049^{* * *} \\
(0.0014)\end{array}$ \\
\hline M2/GDP (initial) & $\begin{array}{l}-0.0064^{* * *} \\
(0.0021)\end{array}$ & $\begin{array}{l}-0.0048^{* *} \\
(0.0022)\end{array}$ & $\begin{array}{l}-0.00097 \\
(0.0054)\end{array}$ & $\begin{array}{l}-0.00094 \\
(0.0053)\end{array}$ \\
\hline Inflation (initial) & $\begin{array}{l}0.00057 \\
(0.00054)\end{array}$ & $\begin{array}{l}0.00075^{*} \\
(0.00043)\end{array}$ & $\begin{array}{l}0.00064^{*} \\
(0.00038)\end{array}$ & $\begin{array}{l}0.00062 \\
(0.00038)\end{array}$ \\
\hline Budget surplus (initial) & $\begin{array}{l}-0.46^{* *} \\
(0.19)\end{array}$ & $\begin{array}{l}-0.80^{* * *} \\
(0.25)\end{array}$ & $\begin{array}{l}-0.69^{* * *} \\
(0.25)\end{array}$ & $\begin{array}{l}-0.65^{\text {*** }} \\
(0.24)\end{array}$ \\
\hline Revolutions & $\begin{array}{l}0.18 \\
(0.55)\end{array}$ & $\begin{array}{l}-0.097 \\
(0.56)\end{array}$ & $\begin{array}{l}-0.50 \\
(0.44)\end{array}$ & $\begin{array}{l}-0.49 \\
(0.44)\end{array}$ \\
\hline Life expectancy (initial) & $\begin{array}{l}0.044 \\
(0.028)\end{array}$ & $\begin{array}{l}0.023 \\
(0.027)\end{array}$ & $\begin{array}{l}0.022 \\
(0.026)\end{array}$ & $\begin{array}{l}0.023 \\
(0.025)\end{array}$ \\
\hline Institutional quality (ICRG) & $\begin{array}{l}1.69^{* * *} \\
(0.51)\end{array}$ & $\begin{array}{l}1.93^{* * *} \\
(0.59)\end{array}$ & $\begin{array}{l}1.57^{* * *} \\
(0.60)\end{array}$ & $\begin{array}{l}1.54^{* * *} \\
(0.58)\end{array}$ \\
\hline Ethnic fractionalization & $\begin{array}{l}-1.97^{* * *} \\
(0.65)\end{array}$ & $\begin{array}{l}-2.08^{* * *} \\
(0.72)\end{array}$ & $\begin{array}{l}-1.63^{*} \\
(0.95)\end{array}$ & $\begin{array}{l}-1.62^{*} \\
(0.93)\end{array}$ \\
\hline Percentage of tropical area & $\begin{array}{l}0.21 \\
(0.42)\end{array}$ & $\begin{array}{l}0.44 \\
(0.39)\end{array}$ & $\begin{array}{l}0.18 \\
(0.41)\end{array}$ & $\begin{array}{l}0.15 \\
(0.40)\end{array}$ \\
\hline Sub-Saharan Africa dummy & & & $\begin{array}{l}-0.61 \\
(0.79)\end{array}$ & $\begin{array}{l}-0.63 \\
(0.76)\end{array}$ \\
\hline East Asia dummy & & & $\begin{array}{l}1.22^{* *} \\
(0.48)\end{array}$ & $\begin{array}{l}1.25^{* * *} \\
(0.47)\end{array}$ \\
\hline TA pc & $\begin{array}{l}0.030^{* *} \\
(0.015)\end{array}$ & $\begin{array}{l}0.031 \\
(0.024)\end{array}$ & $\begin{array}{l}0.033^{* *} \\
(0.016)\end{array}$ & $\begin{array}{l}0.035^{* *} \\
(0.015)\end{array}$ \\
\hline TA pc $\times$ frag. & $\begin{array}{l}-0.00071^{*} \\
(0.00037)\end{array}$ & $\begin{array}{l}-0.0013^{* * *} \\
(0.00044)\end{array}$ & $\begin{array}{l}-0.0011^{* * *} \\
(0.00034)\end{array}$ & $\begin{array}{l}-0.0011^{* * *} \\
(0.00033)\end{array}$ \\
\hline Donor Fragmentation & $\begin{array}{l}0.013 \\
(0.016)\end{array}$ & $\begin{array}{l}0.018 \\
(0.019)\end{array}$ & $\begin{array}{l}0.021 \\
(0.016)\end{array}$ & $\begin{array}{l}0.021 \\
(0.015)\end{array}$ \\
\hline $\begin{array}{l}\mathrm{N} \\
\mathrm{R} \text {-squared } \\
\text { adj. R-squared } \\
\text { Hansen Over-id test }\end{array}$ & $\begin{array}{l}83 \\
0.61 \\
0.53\end{array}$ & $\begin{array}{l}83 \\
0.53 \\
0.43\end{array}$ & $\begin{array}{l}83 \\
0.61 \\
0.52\end{array}$ & $\begin{array}{l}83 \\
0.62 \\
0.53 \\
0.4315\end{array}$ \\
\hline $\begin{array}{l}\text { Dependent Variable in all eq } \\
5 \% \quad * * *: 1 \% \text {. Robust sta }\end{array}$ & $\begin{array}{l}\text { ns is average } \\
d \text { errors are } i\end{array}$ & $\begin{array}{l}\text { vth rates. } \mathrm{Si} \\
\text { enthesis. } \mathrm{Co}\end{array}$ & $\begin{array}{l}\text { cance levels } \\
\text { it term is not }\end{array}$ & $\begin{array}{l}*: 10 \quad * * \\
\text { orted. }\end{array}$ \\
\hline
\end{tabular}

Published by The Berkeley Electronic Press, 2009 


\subsection{Sensitivity to the Normalization of Aid}

Throughout the paper we normalized aid by dividing it by the population of recipient countries. To divide aid by GDP, however, is the aid normalization typically used in the literature. We prefer to use aid per capita mostly for econometric reasons. Dividing aid by GDP introduces an additional potential source for endogeneity. Table 6 shows the results when using aid divided by GDP instead of aid per capita. TA divided by GDP is positive and significant in all columns, except Column (5). Table 6 is essentially a duplication of Table 3 with the exception that we now use aid divided by GDP. We can conclude that our main result is robust to the aid normalization used. However, when comparing Table 3 with Table 6 we can see that in Table 6 the result depends more on the exact specification used. This, however, is expected. Since our aid measure has now being divided by GDP, a country that performs well will have a low aid divided by GDP value but a high growth of income per capita, thereby introducing a downward bias. What Table 6 reveals is that if TA/GDP is used then it is particularly important to adequately control for cross country heterogeneity in steady state income levels. The investment rate, for example, is an important control variable. ${ }^{27}$ For this reason, our preferred aid normalization is to use aid per capita instead of aid divided by GDP.

\section{Conclusions}

In this paper we show, first, that aid effectiveness depends on the type of aid, and, second, that aid effectiveness depends on the fragmentation level of aid. The type of aid matters because different types of aid enter differently into an economy. We argued that NTA enters into the economy through the resource constraint. We developed a model that shows that this form of aid may not increase income growth, namely then when perceived as being permanent. TA, however, affects productivity - via human capital production. This type of aid increases income growth both when perceived as being temporary or permanent. In our empirical analysis we show that NTA does not affect growth rates. In contrast, TA does, provided that its level of fragmentation is sufficiently low. We provide evidence that the effectiveness of TA significantly depends on donor fragmentation. With a low donor fragmentation, the partial impact of TA on income growth is large. For example, increasing TA pc by $\$ 10$ increases annual growth rates by about 0.6 percentage points if donor

\footnotetext{
${ }^{27}$ Excluding the investment rate lowers the point estimate for TA/GDP, because a positive correlation between GDP and income growth and the investment rate respectively means we associate low aid values with high growth rates or high aid values with low growth rates, thereby introducing a downward bias.
} 
Annen and Kosempel: Foreign Aid, Donor Fragmentation, and Economic Growth

Table 6: Sensitivity to the Normalization Choice of Aid

\begin{tabular}{|c|c|c|c|c|c|}
\hline & $(1)$ & $(2)$ & (3) & (4) & $(5)$ \\
\hline Initial GDP pc & $\begin{array}{l}-3.79^{* * *} \\
(0.89)\end{array}$ & $\begin{array}{l}-3.52^{* * *} \\
(0.91)\end{array}$ & $\begin{array}{l}-0.78 \\
(0.77)\end{array}$ & $\begin{array}{l}-3.05^{\text {*** }} \\
(0.87)\end{array}$ & $\begin{array}{l}-2.68^{* * *} \\
(1.02)\end{array}$ \\
\hline Investment/GDP & $\begin{array}{l}1.00 \\
(1.22)\end{array}$ & $\begin{array}{l}1.61 \\
(1.29)\end{array}$ & $\begin{array}{l}2.93^{* *} \\
(1.24)\end{array}$ & $\begin{array}{l}3.26^{* * *} \\
(0.83)\end{array}$ & \\
\hline Openness & $\begin{array}{l}0.030^{*} \\
(0.016)\end{array}$ & $\begin{array}{l}0.026 \\
(0.017)\end{array}$ & $\begin{array}{l}0.019 \\
(0.018)\end{array}$ & & $\begin{array}{l}0.036^{* * *} \\
(0.013)\end{array}$ \\
\hline M2/GDP & $\begin{array}{l}-0.089^{* * *} \\
(0.017)\end{array}$ & $\begin{array}{l}-0.090^{* * *} \\
(0.016)\end{array}$ & $\begin{array}{l}-0.094^{* * *} \\
(0.021)\end{array}$ & & $\begin{array}{l}-0.10^{* * *} \\
(0.017)\end{array}$ \\
\hline Inflation & $\begin{array}{l}-0.00100^{* *} \\
(0.00043)\end{array}$ & $\begin{array}{l}-0.00087^{* *} \\
(0.00042)\end{array}$ & $\begin{array}{l}-0.0011^{* *} \\
(0.00051)\end{array}$ & & $\begin{array}{l}-0.0011^{* *} \\
(0.00047)\end{array}$ \\
\hline Budget balance/GDP & $\begin{array}{l}0.00048 \\
(0.012)\end{array}$ & $\begin{array}{l}-0.012 \\
(0.012)\end{array}$ & $\begin{array}{l}-0.012 \\
(0.016)\end{array}$ & & $\begin{array}{l}-0.0067 \\
(0.0074)\end{array}$ \\
\hline Revolutions & $\begin{array}{l}-0.57 \\
(0.38)\end{array}$ & $\begin{array}{l}-0.69^{*} \\
(0.40)\end{array}$ & & $\begin{array}{l}-1.00^{* *} \\
(0.39)\end{array}$ & $\begin{array}{l}-0.85^{\text {** }} \\
(0.41)\end{array}$ \\
\hline Life expectancy & $\begin{array}{l}0.31^{* * *} \\
(0.066)\end{array}$ & $\begin{array}{l}0.29^{* * *} \\
(0.070)\end{array}$ & & $\begin{array}{l}0.23^{* * *} \\
(0.072)\end{array}$ & $\begin{array}{l}0.27^{* * *} \\
(0.064)\end{array}$ \\
\hline TA/GDP & $\begin{array}{l}234.0^{* *} \\
(112.8)\end{array}$ & $\begin{array}{l}253.2^{* *} \\
(121.3)\end{array}$ & $\begin{array}{l}278.6^{* *} \\
(116.0)\end{array}$ & $\begin{array}{l}281.2^{* *} \\
(123.7)\end{array}$ & $\begin{array}{l}184.8 \\
(118.3)\end{array}$ \\
\hline TA/GDP $\times$ frag. & $\begin{array}{l}-3.41^{* *} \\
(1.69)\end{array}$ & $\begin{array}{l}-3.72^{* *} \\
(1.73)\end{array}$ & $\begin{array}{l}-3.74^{* *} \\
(1.73)\end{array}$ & $\begin{array}{l}-4.03^{* *} \\
(1.73)\end{array}$ & $\begin{array}{l}-2.70 \\
(1.67)\end{array}$ \\
\hline NTA/GDP & $\begin{array}{l}-3.95 \\
(15.5)\end{array}$ & & & & \\
\hline Donor Fragmentation & $\begin{array}{l}0.045 \\
(0.030)\end{array}$ & $\begin{array}{l}0.042 \\
(0.033)\end{array}$ & $\begin{array}{l}0.046 \\
(0.036)\end{array}$ & $\begin{array}{l}0.035 \\
(0.034)\end{array}$ & $\begin{array}{l}0.034 \\
(0.033)\end{array}$ \\
\hline $\mathrm{N}$ & 621 & 621 & 621 & 621 & 621 \\
\hline Hansen over-id test & 0.955 & 0.450 & 0.310 & 0.346 & 0.260 \\
\hline $\mathrm{AB}(1) p$-value & 0 & 0 & 0 & 0 & 0 \\
\hline $\mathrm{AB}(2) p$-value & 0.824 & 0.778 & 0.839 & 0.898 & 0.812 \\
\hline
\end{tabular}

fragmentation is zero, whereas this effect drops to 0.15 if donor fragmentation is $50 \%$. We find a strong interaction effect between TA and donor fragmentation no matter the exact specification, time frame, or aid normalization we use.

One of the main conclusions of this paper is that donor fragmentation seems to introduce inefficiencies thereby significantly reducing the effectiveness of technical assistance. This paper provides empirical evidence for the view that asks for a better coordination among donor countries to improve the effectiveness of foreign aid.

According to growth accounting studies, differences in levels of GDP per person between the wealthiest and poorest countries are due primarily to differences in the production function residual; whereas only a small amount is accounted for by 
differences in physical capital intensity (see Hall and Jones, 1999). As such, one would think that the policies that will be most effective in reducing international income disparities will be the ones that help reduce the productivity gap, and by promoting the accumulation of human capital this is exactly what technical assistance is intended to do. This paper demonstrated that when foreign aid takes the form of technical assistance it can be effective at improving economic conditions in poor countries, at least when it is administered efficiently.

\section{Appendix}

Table 7: Countries in the Sample

\begin{tabular}{|c|c|c|}
\hline$\overline{\overline{\text { Albania }}}$ & "Ghana & Oman \\
\hline Algeria & Grenada* & Pakistan \\
\hline Argentina & Guatemala & Papua New Guinea \\
\hline Azerbaijan & Guinea-Bissau & Paraguay \\
\hline Bahamas, The & Haiti & Peru \\
\hline Bahrain & Honduras & Philippines \\
\hline Bangladesh** & India & Rwanda* \\
\hline Barbados* & Indonesia & Saudi Arabia \\
\hline Belize* & Iran, Islamic Rep. & Senegal \\
\hline Bhutan* & Jamaica & Sierra Leone \\
\hline Bolivia & Jordan & Singapore \\
\hline Botswana & Kazakhstan & Slovenia \\
\hline Brazil & Kenya & Solomon Islands* \\
\hline Burkina Faso & Korea, Rep. & South Africa \\
\hline Burundi* & Kuwait & Sri Lanka \\
\hline Cambodia* & Kyrgyz Republic* & St. Kitts and Nevis* \\
\hline Cameroon & Lebanon & St. Lucia* \\
\hline Chad* $^{*}$ & Lesotho* & St. Vincent and the Grenadines* \\
\hline Chile & Macedonia, FYR* & Sudan \\
\hline China & Madagascar & Suriname \\
\hline Colombia & Malawi & Swaziland* \\
\hline Congo, Dem. Rep. & Malaysia & Tanzania \\
\hline Congo, Rep. & Maldives* & Thailand \\
\hline Costa Rica & Mali & Togo \\
\hline Cote d'Ivoire & Malta & Tonga* \\
\hline Croatia & Mauritania* & Trinidad and Tobago \\
\hline Cyprus & Mauritius* & Tunisia \\
\hline Djibouti* & Mexico & Turkey \\
\hline Dominican Republic & Moldova & Uganda \\
\hline Ecuador & Mongolia & Uruguay \\
\hline Egypt, Arab Rep. & Morocco & Venezuela, RB \\
\hline Ethiopia & Namibia** $^{* *}$ & Vietnam \\
\hline Fiji* & Nepal$^{*}$ & Yemen, Rep. \\
\hline Gabon & Nicaragua & Zambia \\
\hline Gambia, The & Niger & Zimbabwe \\
\hline Georgia* & Nigeria & \\
\hline
\end{tabular}


Annen and Kosempel: Foreign Aid, Donor Fragmentation, and Economic Growth

Table 8: Data Source

\begin{tabular}{|c|c|c|}
\hline$\overline{\text { Variable }}$ & Definition & Source \\
\hline$\overline{\mathrm{GDP}} \mathrm{pc}$ & $\begin{array}{l}\text { GDP per capita PPP adj. } \\
\text { in } \$ 2000 \text {. }\end{array}$ & Penn World Tables 6.2 \\
\hline Investment/GDP & $\begin{array}{l}\text { Investment share of real } \\
\text { GDP in } \$ 2000 \text {. }\end{array}$ & Penn World Tables 6.2 \\
\hline Openness & $\begin{array}{l}\text { Exports and Imports divided } \\
\text { by real GDP }(\$ 2000)\end{array}$ & Penn World Tables 6.2 \\
\hline M2/GDP & $\begin{array}{l}\text { M2 dividid by GDP both } \\
\text { in local current currency }\end{array}$ & World Development Indicators \\
\hline Inflation & $\begin{array}{l}\text { Yearly consumer price } \\
\text { inflation }\end{array}$ & World Development Indicators \\
\hline Budget balance & $\begin{array}{l}\text { Budget surplus divided by } \\
\text { GDP both in local current } \\
\text { currency or US dollars }\end{array}$ & Financial Statistics IMF \\
\hline Revolutions & $\begin{array}{l}\text { Number of revolutions } \\
\text { per year }\end{array}$ & Arthur S. Banks \\
\hline Life expectancy & $\begin{array}{l}\text { Life expectancy at birth } \\
\text { in years }\end{array}$ & World Development Indicators \\
\hline TA & $\begin{array}{l}\text { Technical Cooperation } \\
\text { PPP in } \$ 2000 \text {. }\end{array}$ & OECD.stat \\
\hline NTA & See discussion in text & OECD.stat \\
\hline Colony & Data on colonial history & CEPII Research Center \\
\hline Language & Common language & CEPII Research Center \\
\hline Population & & Penn World Tables 6.2 \\
\hline Democracy & & Freedom House \\
\hline Institutional Quality & & International Country Risk Guide \\
\hline Ethnic Fractionalization & & $\begin{array}{l}\text { Philip G. Roeder. } 2001 . \\
\text { Ethnolinguistic Fractionalization } \\
\text { (ELF) Indices, } 1961 \text { and } 1985 .\end{array}$ \\
\hline $\begin{array}{l}\text { Percentage of } \\
\text { tropical area }\end{array}$ & & $\begin{array}{l}\text { GEO-data, Gallup, John L. } \\
\text { and Jeffrey D. Sachs (1999) }\end{array}$ \\
\hline
\end{tabular}


The B.E. Journal of Macroeconomics, Vol. 9 [2009], Iss. 1 (Contributions), Art. 33

Table 9: Estimation of exogenous variation in TA pc by donors across recipients

\begin{tabular}{ll} 
Dummy for pairs that ever had a colonial relationship & -2.23 \\
Dummy for pairs that have common language & $(2.20)$ \\
& $2.28^{* * *}$ \\
Dummy for country that ever had a colonial relationship with U.K. & $-0.82^{* * *}$ \\
& $(0.18)$ \\
Dummy for country that ever had a colonial relationship with France & $-1.05^{* * *}$ \\
& $(0.28)$ \\
Dummy for country that ever had a colonial relationship with Spain & $-0.47^{* * *}$ \\
& $(0.15)$ \\
Dummy for country that ever had a colonial relationship with Portugal & 0.38 \\
& $(0.38)$ \\
Ratio of logarithm of population of donor relative to recipient & $0.56^{* * *}$ \\
& $(0.18)$ \\
Ratio of logarithm of population $\times$ colony dummy & $4.69^{* * *}$ \\
Ratio of logarithm of population $\times$ U.K. colony dummy & $(1.20)$ \\
Ratio of logarithm of population $\times$ France colony dummy & -0.23 \\
Ratio of logarithm of population $\times$ Spain colony dummy & $(0.22)$ \\
Ratio of logarithm of population $\times$ Portuguese colony dummy & 0.52 \\
\hline N & $(0.36)$ \\
adj. R-squared & -0.31 \\
\hline \hline Dependent Variable in all equations is TA pc. Significance levels : $*: 10$ & $* *: 5 \%$ \\
& $* * * 30)$
\end{tabular}

\section{References}

Agenor, P.-R., N. Bayraktar, and K. E. Aynaoui (2008): "Roads out of Poverty? Assessing the links between Aid, Public Investment, Growth, and Poverty Reduction," Journal of Development Economics, 86(2), 277-295.

Amegashie, J. A., B. Quattara, and E. Strobl (2007): "Moral Hazard and the Composition of Transfers: Theory with an Application to Foreign Aid," Working Paper, Department of Economics, University of Guelph.

Arellano, M., And S. Bond (1991): "Some Tests of Specification for Panel Data: Monte Carlo Evidence and an Application to Employment Equations," Review of Economic Studies, 58, 277-297.

Barro, R. J., And X. SAla-i Martin (2004): Economic Growth. MIT Press, Cambridge, Mass. 
Annen and Kosempel: Foreign Aid, Donor Fragmentation, and Economic Growth

Blundell, R., AND S. Bond (1998): "Initial Conditions and Moment Restrictions in Dynamic Panel Data Models," Journal of Econometrics, 87, 115-143.

Boone, P. (1996): "Politics and the Effectiveness of Foreign Aid," European Economic Review, 40(2), 289-329.

Bourguignon, F., And M. Sundberg (2007): "Aid Effectiveness - Openning the Black Box," American Economic Review, 97(2), 316-321.

Brambor, T., W. R. Clark, And M. Golder (2006): "Understanding Interaction Models: Improving Emprical Analyses," Political Analysis, 14, 63-82.

Burnside, C., And D. Dollar (2000): “Aid, Policies, and Growth,” American Economic Review, 90(4), 847-868.

CAss, D. (1965): “Optimum Growth in an Aggregate Model of Capital Accumulation," Review of Economic Studies, 32(July), 233-240.

Chatterjee, S., S. G., and S. J. Turnovsky (2003): "Unilateral Capital Transfers, Public Investment and Economic Growth," European Economic Review, 47, 1077-1103.

Chatterjee, S., P. Giuliano, and K. Ilker (2007): "Where Has All the Money Gone? Foreign Aid and the Quest for Growth,” IZA-Discussion Paper.

Chatterjee, S., And S. J. Turnovsky (2007): "Foreign Aid and Economic Growth: The Role of Flexible Labor Supply," Journal of Development Economics, 84, 507-533.

Clemens, M., S. Radelet, and R. Bhavnani (2004): "Counting Chickens When They Hatch: The Short Term Effect of Aid on Growth," Working Paper Center for Global Development 44.

DalgaArd, C.-J., H. Hansen, And F. TARP (2004): “On the Empirics of Foreign Aid and Growth,” Economic Journal, 114, F191-F216.

Devarajan, S., And V. Swaroop (1998): “The Implication of Foreign Aid Fungibility for Development Assistance," Policy Research Working Paper Series, World Bank, 2022.

EAsterly, W. (2003): “Can Foreign Aid Buy Growth?," Journal of Economic Perspectives, 17(3), 23-48.

Easterly, W., R. Levine, and D. Roodman (2004): "Aid, Policies, and Growth: Comment," American Economic Review, 94(3), 774-780. 
The B.E. Journal of Macroeconomics, Vol. 9 [2009], Iss. 1 (Contributions), Art. 33

Glaeser, E. L., R. La Porta, F. Lopez-de Silanes, and A. Shleifer (2004): “Do Institutions Cause Growth?,” NBER Working Paper, Nr. 10568.

Hall, R. E., AND C. I. Jones (1999): "Why do some Countries Produce so much more Output per Worker than others?," Quarterly Journal of Economics, 114, 83-116.

Hodler, R. (2007): "Rent Seeking and Aid Effectiveness," International Tax and Public Finance, 14(5), 525-541.

Judson, R., And A. L. Owen (1996): "Estimating Dynamic Panel Data Models: A Practical Guide for Macroeconomicsts," Working paper, Federal Reserve Board of Governors.

KNACK, S., AND A. RAHMAN (2007): "Donor Fragmentation and Bureaucratic Quality in Aid Recipients," Journal of Development Economics, 83(1), 176-197.

Koopmans, T. C. (1965): "On the Concept of Optimal Economic Growth," The Econometric Approach to Development Planning.

Mankiw, G., D. Romer, And D. Weil (1992): "A Contribution to the Empirics of Economic Growth," Quarterly Journal of Economics, 107, 407-37.

Minoiu, C., And S. G. Reddy (2009): "Development Aid and Economic Growth: A Positive Long-Run Relation," SSRN eLibrary.

Rajan, R. G., And A. Subramanian (2008): "Aid and Growth: What does the Cross-Country Evidence Really Show?," The Review of Economics and Statistics, 90(4), 643-665.

RAMSEY, F. (1928): "A Mathematical Theory of Savings," Economic Journal, 38(December), 543-559.

RIDDELl, R. (2007): Does Foreign Aid Really Work? Oxford University Press, Oxford.

Roodman, D. (2006): “An Index of Donor Performance," Working Paper Center for Global Development, 67.

(2009): "How to do xtabond2: An introduction to difference and system GMM in Stata," Stata Journal, 9(1), 86-136.

Woolbridge, J. (2002): Econometric Analysis of Cross Section and Panel Data. MIT-Press, Boston, Cambridge Mass. 